\title{
Benchmarking: An International Comparison
}

Greg Tower, (Email: Greg.Tower@ cbs.curtin.edu.au), Curtin University of Technology, Australia Brenda Ridgewell, Curtin University of Technology, Australia

\begin{abstract}
The study examines the impact of national research assessment exercises for the accounting and visual arts disciplines. Analysis is also made of the impact of a 'national research quality assessment exercise' of New Zealand and UK initiatives (Tertiary Education Commission. 2004; RAE, 2001) and well as the proposed Australian RQF (2005). We find that whilst the definition of research is broad enough to include most of the activities of accounting and finance, and visual arts academia the actual measures of research performance may be problematic. The need to clearly demonstrate quality peer review is the largest hurdle especially for visual arts academics with their individualist and independent mindset. Whilst visual arts and, accounting and finance academia research performance activity was ranked low in both the UK and NZ, we conclude that that the focus on output quality and peer assessment offers a potentially broader and more accurate depiction of activity. Obtaining a balanced broader assessment of both traditional performance measures such as research publications of accounting and finance along with the more creative elements of visual arts such as exhibitions is paramount. We also make a call for more research training for both disciplines to assist them in the recognition of quality research productivity.
\end{abstract}

\section{INTRODUCTION}

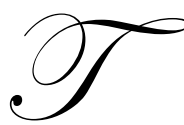

his study compares national research performance assessment models in the United Kingdom, New Zealand and Australia for business and humanities academics. It specifically focuses on accounting and visual art academics as prime examples of academic disciplines that need to be cognizant of fundamental changes in how their research performance is evaluated and measured. The study examines the issue of benchmarking research productivity and the usage of appropriate performance indicators to accurately measure performance. These measures are causing fundamental changes in the management of performance, incentives and reward structures.

This introduction is followed by a section that examines the issue of benchmarking research. Then each of the three national research assessment models (United Kingdom, New Zealand and Australia) is reviewed. Specific focus is given to how these models have and will affect the accounting and visual art academics. Future portents are then discussed via an interpretive analysis of the strengths and weaknesses of these models with a final conclusion on the likely impact on business and humanities academics.

\section{BENCHMARKING RESEARCH}

Teaching, research and service are the three key contributions of universities and their academic staff. This study focuses on the research activity aspect. Arguably there is a world wide movement by governments to encourage (or force) universities to be more efficient with their research dollars. Governments, as the biggest funding resource for universities, expect high value for the money they grant the tertiary institutions.

A broad range of performance indicators are used to demonstrate the universities' productivity. The two major foci are firstly efficiency which is the ability to be efficient with expenses and outlays (cost-savings) and secondly effectiveness the ability of a university to show clear links to costs and the related benefits generated. These 
terms are defined as cost-savings and cost-controls; and the benefit of the research as compared to the cost to produce it, respectively.

A university's research performance is measured in terms of inputs, outputs and outcomes. A typical input measure would be external research income received. Arguably an input is less important as it is a measure of efficiency whereas effectiveness indicators such as outputs and outcomes are considered more vital. Research publications such as journal articles and scholarly books are the key research outputs. Another important output measures include postgraduate research student completions. Research outcomes, such as the improvement of a society's living standards are much harder to measure. Steps are being undertaken to get a better handle on possible research outcomes. For instance, the British Research Assessment Exercise is placing more emphasis on measuring the 'impact' of research on society. An example is contained in the UK Research Assessment Exercise Panel on Art and Design when they state "In assessing the quality of research outputs, the Panel will assess the significance to the relevant discipline. In so doing, the panel will refer to ... level of innovation ... contribution to knowledge ... and accessibility to future generations" (www.hero.ac.uk/rae/criteria/crit64.htm para.3.55.15, 2005).

The British RAE criteria for Art and Design have a mixture of content measures, context, external validation and some references to outcomes. It argues the content criteria include level of innovation and quality. Contextual examples would be items such as the frequency of circulation and scale of competition. More problematic is the outcome criteria which would seek to quantify the level of contribution and accessibility to future generations. These latter criteria are arguably critically important but very difficult to measure.

Globally, there are different country models for assessing research performance. The United Kingdom and New Zealand are now implementing national research assessment procedures to measure outputs and outcomes (Tertiary Education Commission, 2004), whereas Australia has historically used a research quantum based on funding research on inputs, such as national competitive research grant track record (RQF, 2005a). However, Australia is moving rapidly to fundamentally change their approach and is adopting the British-style assessment exercise using a criterion of peer assessment to measure the academic disciplines research performance and related contribution to society. These assessment exercises measure the quality of the research outputs as a proxy value for quantifying research outcomes (Ridgewell and Tower, 2005).

\section{NATIONAL RESEARCH ASSESSMENT MODELS}

All the above discussion puts the major emphasis on the quality and importance/impact of the research. Thus, the definition of research and how it is measured is vitally important (Lucas, 2004). This study focuses on two different university disciplines: accounting (as a business example) and visual arts (as a humanities example). Accounting academics traditionally are professional accredited (CA and CPA being the main designations) with very large teaching hours and student numbers. Research has not usually been the chief focus instead quality teaching and professional liaisons were historically the key performance criteria. This is now rapidly changing with the steady increase in the number of doctoral qualified staff and rising research expectations. These research expectations are focused on the production of scholarly journal articles, book chapters and books. The need for peer review through a refereeing process is paramount.

In contrast, visual arts is a non-traditional academic field. This discipline attracts creative and independent individuals not used to the structure of research groupings, external grant pursuits and documenting the peer esteem of their research. Ridgewell and Tower (2005, p.6) define practice-based as the "recognition of the creative output focus such as the development of creative works for exhibit, such as the making of jewellery for show". They state that such visual art academics are now expected to disseminate research output in two very different and distinct categories: practice-based works for art exhibit and scholarly writings in refereed journals. This is especially problematic in that research assessment exercises may increase the importance of visual arts academics to demonstrate their contribution in the academic scholarly domain as well as the production of artworks for exhibit.

Ridgewell and Tower (2005) also argue that the research assessment exercises are cognizant of such concerns and have correspondingly adopted broad and inclusive definitions of research. For example the British Research 
Assessment Exercise defines research as "...original investigation undertaken in order to gain knowledge and understanding... the invention and generation of ideas, images, performances and artefacts including design, where these lead to new or substantially improved insights; and the use of existing knowledge in experimental development to produce new or substantially improved materials, devices, products and processes, including design and construction" (http://195.194.167.103/Pubs/other/raeguide.pdf, 2005). Thus, this definition allows for both accounting style scholarly style research and more practice based visual arts investigation/research to be recognised.

Similarly, the New Zealand research assessment exercise defines the creative side of research as “...original investigation undertaken in order to gain knowledge and understanding... In some fields, the results of the investigation may be embodied in the form of an artistic work, design or performance...It also includes the experimental development of design or construction solutions, as well as investigation that leads to new or substantially improved materials, devices, products or processes. (http://www.otago.ac.nz/research/pbrf/\#definition, 2005). Arguably, this definition directly lists artistic work as a research/ investigation process. This provides a starting point for recognition that the other definitions excluded or hide under the umbrella of design, construction or things.

The proposed new definition of research in Australia states that research is "creative work undertaken on a systematic basis in order to increase the stock of knowledge" (RQF, 2005a). Ridgewell and Tower (2005) note that this Australian definition may limit the more creative elements such as those found in the visual arts and other humanities performing art fields. Upon reflection, this definition appears to limit more creative elements such as those found in the performing arts. However, the accounting discipline style of research fits comfortably within these research definitions. A major concern is that, a key ingredient, the method of assessment of research is not clearly defined.

Hong Kong adopted a similar policy and approach to the UK RAE. However, it is worth noting that the outputs used for assessment in the Hong Kong RAE are sufficiently loosely defined to allow for more varied measures than those that support standard academic research excellence such as publications (RQFa, 2005). "This broader definition of an output also allows for creative performance, exhibitions and other items to be nominated for assessment so long as they are 'publicly accessible' through video, photographs, or some other submittable format (RQF, 2005, Appendix C). Lucas (2004) notes that the Hong Kong variant of the RAE improved the definition of research by adopting the Carnegie (1990) broader concept of 'scholarship' with the intention to allow for more creative and innovative research activity. This may allow for a wider perspective through the consideration of a wider arrange of societal needs such as passion, interpretation, dynamism and extension (Ridgewell and Tower, 2005). This broader definition of output also allows for creative performance, exhibitions and other items to be nominated for assessment so long as they are publicly accessible through video photographs or some other submittable format (RQF, 2005a).

As all these above definitions were intended to be broadly worded to include a wide range of research output but still excluding teaching and consulting activities. However, scholarly writing, as referred by peers is still the most valued for of research. Lucas (2004) states "It seemed that for both the individual involved in RAE submission and for the RAE panel members the criteria for evaluating the scholarship of discovery or the traditional basic research category was perceived to more straightforward ..." [it] "not only more apparent in terms of how it can be evaluated but that it ultimately carries more prestige than other forms of scholarship" (Lucas, 2004,7)

How research is assessed across disciplines from the traditional written paper (such as the accounting academic focus) to the practice based research of contemporary universities may well be a major concern for practice based researchers (such as visual arts academic focus). The next section of this paper explores the actual RAE performance measures of visual arts and accounting academics in Britain and New Zealand to see how well they were deemed to perform. 


\section{ACTUAL PERFORMANCE MEASURES OF ACCOUNTING AND VISUAL ARTS ACADEMICS}

The OECD (1987, p.19) notes the mounting level of concern about "the increasing cost of funding university-based research". This is clearly true in Australia where now the federal government is stressing the increasing need for research evaluation (RQF, 2005a). At present Australia has a partial performance-based component using quantitative indicators such as the amount of external funding (Geuna \& Martin, 2003). A review of three key national research assessment approaches is contained in Table 1. Table 1 reviews the key elements and adds a comparative commentary column which compares the British, New Zealand and Australian approach and reviews strengths and weaknesses.

Table 1: Key Components Of The UK Research Assessment Exercise, New Zealand Performance-Based Research Fund \& Australian Research Quality Framework Component/Details
Allocation of funds
Virtually all of the United Kingdom funding bodies' research
income is directed based on the RAE findings. In Australia,
no new funds will be given in the new round, but up to
A $\$ 900$ million dollars of research funds may be reallocated
across the universities based on the RQF findings. In New
Zealand only NZ $\$ 18$ million was allocated on the first PBRF
round in 2003 but the expectation is that (like the UK) all
research funding will be based on the national assessment
findings. Percentage of academics assessed

The New Zealand quality evaluation involves the direct assessment of $100 \%$ of the individual academic staff members. In the UK, the universities 'selected' academic staff to be rated in discipline-based groups. Thus a far lower percentage was assessed. Australia is likely to go in between these approaches. It is thought that $50-80 \%$ of Lecturer staff and above will be assessed.

Unit of Evaluation

In the UK and NZ the academic unit (such as accounting and finance) was the unit. The UK had 65 such discipline categories whilst New Zealand had only 41. Australia is planning to take a different approach by allowing each university to nominate 'research groupings.

Evidence portfolios and the assessment framework

In New Zealand the research component is comprised of up to four 'nominated research outputs' as well as up to 50 percent of 'other research outputs'. The research component had a $70 \%$. The peer esteem component is comprised of the recognition of a staff members' research by his peers and has $15 \%$ weighting. The contribution to research environment component comprises a staff member's contribution to a vital high-quality research environment and has a $15 \%$ weighting (including both research income and postgraduate research supervision).

\section{Definition of Research}

A broad array of research outputs is evaluated in each of the countries. This include items such as : Artefact/object, Film/video, Software, Design output, Exhibition, Performance, Authored book, Chapter in book, Conference contribution, Journal Article Commentary

The federal governments of all three countries have clearly shown a preference to 'focus' their research dollars on those institutions rated the highest in the national research assessment exercises. The result will be clearly distinctive tiering of universities into funding bands and their concurrent ability to conduct research.

The breadth of the assessment coverage varies widely across countries. Arguably, the New Zealand decision to include all academics is by far the broadest and most comprehensive approach. The Australian RQF is likely to include at $50 \%$ of academics whereas in the UK universities are allowed to pick and choose who would be assessed.

These percentages matter in that the traditional universities are likely to have a greater percentage of research active staff and thus far better in the overall assessment.

The Australian approach may encourage more interdisciplinary research. However, it is problematic in that the research groupings will not be directly comparable. Moreover, in may be very difficult for universities to reconcile the need to assess at least $50 \%$ of academic staff within 'research groups' .

This weighting is very similar to the British RAE and proposed Australian approach. It should be noted that these greatly differ from the present Australian system that assigns only $10 \%$ to publications, $0 \%$ to peer esteem, $60 \%$ to grants and $30 \%$ to postgraduate research student completions.

As discussed in Section 3, each country is allowing a wide list of possible research items. Thus, this list incorporates the traditional journal articles used by accounting academics as well as exhibits for visual arts academics.

Sources: UK RAE, 2001; Tertiary Education Commission, 2004; RQF, 2005 
There are several stated advantages of all of these national research assessment exercises. The prime one is that it allows for more comprehensive information on the quality of research being undertaken thus providing for a more effective mechanism for allocating funds. Such evaluation is first conducted on the individual researcher and then aggregated into discipline and institutional level. In each country the top four publications over a four to seven year period is the primary point of assessment. Overall, the RAE is a peer review evaluation. Selection of the peer review panel members are based on factors such as eminence of individuals, convergence of the subject, and sectoral and geographical balance.

Table 1 shows the similarities and differences in scope group/discipline, the breadth of number of individuals chosen and the actual criteria used in each country. The British RAE began in 1983 and has been conducted five times with a sixth one in 2008. In the UK the focus is on a discipline (such as accounting and finance). Not all British academics are selected for evaluation; instead each university chooses which staff will be put forth. Each university has to struggle with the competing need to only nominate those academics likely to be rated the highest versus the financial pressures of nominating as many as possible. Anecdotal evidence suggests the university are parsimonious with their selection criteria by choosing only a highly regarded subset of the 'best researchers'.

Each academic submits their four best research outputs (usually scholarly journal articles). On the basis of this information the review panel assigned a rating of 1 to 5 to each of the university's discipline put forth (note the 2008 RAE will only be using a 1-4 rating system). The UK research funding bodies use the rating in the formula applied to determine the research the funding for each unit of assessment, with the total block grant received being calculated by summing across all units (RQF, 2005). Informal and formal league tables use the data to rank UK universities (see for instance the Education Guardian (2005) 'RAE Tables'. These 'league tables' are heavily scrutinised and powerful image makers for the UK universities. Performance management has been heavily effected via staff hiring, firings, promotions and annual evaluations all placing a far heavier emphasis on research performance than was previously the case.

The New Zealand federal government adopted a first ever national research exercise in 2003 (see Table 1); this was termed the 'Performance Based Research Fund [PBRF]. There are several key points in regards to its structure. First, the overall score is based on $60 \%$ for peer review assessment, $25 \%$ for research degree completions and $15 \%$ for external research income earnings. The emphasis on peer assessment judged outputs arguably is fairer than a research income biased approach. Second, the NZ PBRF provides an example of a more recently established research assessment process in which the individual researcher is the focal point for assessment. Unlike the UK RAE, but similar to earlier Hong Kong RAE the NZ PBRF involves the direct assessment of all individual academic staff rather than academic units. This could disadvantage 'young' disciplines such as visual arts and accounting, however, it would allow for a more complete picture of the current state of play of the entire discipline. Third, the PBRF is a mechanism for distributing funding as well as existing funding on the basis of the highest quality researchers. Accounting and visual arts academics may be a net loser out of such a structure. Finally, the NZ PBRF is differentiated from earlier models by a clearly stated funding formula that combines peer review with performance indicator measures. The peer review component arguably allows for visual arts and accounting academics to be judged by their peers on discipline-appropriate criteria (RQF, 2005a, Tertiary Education Commission, 2004, Ridgewell and Tower, 2005).

The New Zealand government body, Tertiary Education Commission (2004), felt its initial 2003 assessment exercise was very successful. It states it is confident that the results of the 2003 quality evaluation provide an impetus for tertiary bodies to review their research plans and strategies. The Commission also admits that many New Zealand academics felt that their research efforts have not been properly recognized. Especially problematic was their decision to use the same criteria for both senior researchers as well as early career researchers (e.g. those just finishing their doctorates). The result was arguably an overly harsh measure. Moreover, the inclusion of all academics, whilst comprehensive, resulted in very low overall scores (2.6 on a ten point scale). The forthcoming research exercise in Australia (Research Quality Framework) combines aspect of both the United Kingdom and New Zealand models. Negotiations are still being conducted over the scope of the exercise. A thorny issue is the choice to focus on 'research groups' versus academic disciplines (Table 1). Whilst potentially encouraging multidisciplinary research it is far less comparable. Moreover, the final decision concerning the percentage of staff to be evaluated has not yet 
been made. Currently the debate centers on between $50-80 \%$ of academics to be evaluated. This cut-off percentage is very important in terms of the likely aggregate rating a university will be awarded with more established researchoriented institutions lobbying for as high a ratio of staff to be assessed as possible. Tables 2 and 3 detail the actual ratings of accounting and visual art academics in the latest NZ and UK national research evaluations.

Table 2: Visual Art \& Accountants Research Performance In New Zealand Pbrf 2003

\begin{tabular}{|c|c|}
\hline Component/Details & Commentary \\
\hline $\begin{array}{l}\text { The results of the } 2003 \text { Quality Evaluation. } \\
\text { Under the approach adopted, the maximum quality score that can be } \\
\text { achieved by a TEO (subject area or nominated academic unit) is } 10 \text {. In } \\
\text { order to obtain such a score, however, all the PBRF-eligible staff in the } \\
\text { relevant TEO would have to receive an 'A' Quality Category. With the } \\
\text { exception of very small academic units such an outcome is extremely } \\
\text { unlikely. No sizeable academic unit, et alone a large TEO, could } \\
\text { reasonably be expected to secure quality score even close to } 10 \text {. } \\
\text { The low quality score reflects the very large numbers of staff whose } \\
\text { evidence portfolios were assigned an "R". }\end{array}$ & $\begin{array}{l}\text { A major weakness of the New Zealand PBRF is the } \\
\text { harshness of the scale applied. The highest } \\
\text { university (Auckland) received only an aggregate } \\
3.96 \text { score out of ten. This is a low rating that } \\
\text { makes it very hard to 'market' their strengths } \\
\text { internationally. In contrast the UK RAE ranked } \\
39 \% \text { a } 5 \text { or 5* out of a } 0-5^{*} \text { scale allowing for } \\
\text { wide-scaled overseas advertising for their high } \\
\text { ranked universities. }\end{array}$ \\
\hline $\begin{array}{l}\text { Key Findings } \\
\text { The overall FTE-weighted quality score for the } 22 \text { participating TEOs is } \\
2.6 \text { out of a potential } 10 \text {. A relatively high proportion of the PBRF- } \\
\text { eligible staff ( } 39.9 \% \text { FTE weighted) were deemed to not yet meet the } \\
\text { standard requires for achieving a C Quality category and were assigned } \\
\text { an R. } 31.7 \% \text { PBRF-eligible staff (FTE weighted) in the university sector } \\
\text { were assigned to an A or B Quality Category. There are marked } \\
\text { differences in the research performance of the } 41 \text { subject areas. While } \\
\text { some subject areas have a substantial proportion of researchers in the A } \\
\text { and B Quality categories, others have had hardly any. Altogether } 11 \text { of } \\
\text { the } 41 \text { subject areas have a quality range of less than } 2.0 \text { and thus an } \\
\text { average sore within the R range ( } 0 \text { to } 1.99 \text { ). In general the best results } \\
\text { were achieved by long-established disciplines with strong research } \\
\text { cultures such as philosophy, chemistry and psychology. Relatively high } \\
\text { quality scores were achieved by subject areas within the biological and } \\
\text { physical sciences, the humanities and the social sciences. Many subject } \\
\text { areas with low quality scores are newer disciplines such as design; } \\
\text { nursing; sport; exercise science, theatre, dance, film and television and } \\
\text { multimedia. Against this with only a few exceptions, subject areas in the } \\
\text { fields of business and the creative and performing arts had below-average } \\
\text { quality scores. }\end{array}$ & $\begin{array}{l}\text { This very low average was demoralising to New } \\
\text { Zealand academics (Van Peursem, 2004). The } \\
\text { New Zealand PBRF used a uniform expectation } \\
\text { within a peer panel, therefore early career } \\
\text { researchers were ranked downwards. This } \\
\text { approach is arguably very inequitably and } \\
\text { encourages departments into short term strategies } \\
\text { (hire the top guns now) versus more long-range } \\
\text { planning (acquire and grow talented early career } \\
\text { researchers). As discussed in the following section } \\
\text { it is an open question whether these major } \\
\text { differences are a result of a flawed process or } \\
\text { fundamental differences between disciplines. }\end{array}$ \\
\hline $\begin{array}{l}\text { Visual Arts Performance } \\
\text { FTE-weighted quality scores Creative and Performing Arts } 1.99 \text { (Figure } \\
\text { A-2); overall average for all disciplines was } 2.59 \text {. Table A-44 Results } \\
\text { (weighted FTE basis by subject area- Visual Arts and Crafts: Staff Rated } \\
\text { A: } 3.2 \% \text { (overall average for all disciplines }=5.7 \% \text { ), Staff Rated B: } \\
\text { 19.6\% (overall average was } 23.2 \% \text { ), Staff Rated C: } 36.4 \% \text { (overall } \\
\text { average was } 31.2 \% \text { ), and Staff Rated R: } 40.8 \% \text { (overall average was } \\
39.9 \% \text { ). }\end{array}$ & $\begin{array}{l}\text { As stated above, the Visual Arts was ranked } 37 \text { of } \\
41 \text { academic disciplines in the New Zealand PBRF. } \\
\text { The average score of } 1.99 \text { just fell into the bottom } \\
\text { ' } R \text { ' category. Visual arts academics had lower } \\
\text { scores in the top two categories. Interestingly, their } \\
\text { percentage of staff in the non-active research } \\
\text { category (' } R \text { ') was only slightly lower than the } \\
\text { average of all other disciplines. }\end{array}$ \\
\hline $\begin{array}{l}\text { Accounting Performance } \\
\text { FTE-weighted quality scores Business and Economics } 2.16 \text { (Figure A-2); } \\
\text { overall average for all disciplines was } 2.59 \text {. Table A-4 Results (weighted } \\
\text { FTE basis by subject area- Accounting and Finance: Staff Rated A: } 2.8 \% \\
\text { (overall average for all disciplines= } 5.7 \% \text { ), Staff Rated B: } 15.5 \% \text { (overall } \\
\text { average was } 23.2 \% \text { ), Staff Rated C: } 27.7 \% \text { (overall average was } 31.2 \% \text { ), } \\
\text { and Staff Rated R: } 54.0 \% \text { (overall average was } 39.9 \% \text { ) }\end{array}$ & $\begin{array}{l}\text { Accounting and Finance was ranked } 34 \text { of } 41 \\
\text { academic disciplines in the New Zealand PBRF. } \\
\text { The average score of } 2.56 \text { fell into the 'C' } \\
\text { category. Accounting and Finance academics had } \\
\text { lower scores in the top two categories. } \\
\text { Interestingly, their percentage of staff in the non- } \\
\text { active research category ('R') was significantly } \\
\text { higher than the average of all other disciplines. }\end{array}$ \\
\hline
\end{tabular}

Source: Adapted from Ridgewell and Tower (2005) 
Overall, the Accounting and Visual Arts disciplines fair poorly in these national rating by discipline. Table 2 shows that the New Zealand assessment used a very stringent and arguably harsh set of criteria. The best ranked university received less than a four score out of a ten point scale. Plummer (2005) argues that this scale was greatly demeaning to New Zealand academics in that far too many academics and disciplines were given very low ratings. The visual arts were ranked 37 of the 41 disciplines. They had an overall score of less than two of a ten point scale. Accounting and Finance ranked 34 out of the 41 disciplines. They had an overall score of just over two and a half on a ten point scale. Table 2 also highlights that individual academics were considered lower than average across the board with smaller percentages of the two highest categories (A and B) and more in the lowest ' $\mathrm{R}$ " category.

Table 3 illustrates the 2001 overall British RAE results and the specific 'Arts and Design' and 'Accounting and Finance' disciplines.

Table 3: Accounting And Visual Art Research Performance In The U.K.

Compared To The Overall Results Of Performance

\begin{tabular}{|c|c|c|c|c|c|c|}
\hline Grade & $\begin{array}{l}2001 \text { Overall } \\
\text { Results }\end{array}$ & $\begin{array}{l}2001 \text { Overall } \\
\text { Results }(\%)\end{array}$ & $\begin{array}{l}2001 \text { Accounting } \\
\text { and Finance }\end{array}$ & $\begin{array}{l}2001 \text { Accounting } \\
\text { and Finance }(\%)\end{array}$ & $\begin{array}{l}2001 \text { Art and } \\
\text { Design } \\
\text { Results }\end{array}$ & $\begin{array}{c}2001 \text { Art and } \\
\text { Design Results } \\
(\%)\end{array}$ \\
\hline 1 & 18 & 1 & 0 & 0 & 1 & 1.33 \\
\hline 2 & 140 & 5 & 0 & 0 & 5 & 6.67 \\
\hline $3 b$ & 278 & 11 & 1 & 5 & 11 & 14.67 \\
\hline $3 a$ & 499 & 19 & 2 & 10 & 25 & 33.33 \\
\hline 4 & 664 & 26 & 3 & 15 & 21 & 28 \\
\hline 5 & 715 & 28 & 12 & 60 & 12 & 16 \\
\hline $5 *$ & 284 & 11 & 2 & 10 & 0 & 0 \\
\hline Total & 2598 & 100 & 20 & 100 & 75 & 100 \\
\hline Grade & $\begin{array}{c}1996 \\
\text { Overall } \\
\text { Results }\end{array}$ & $\begin{array}{c}1996 \\
\text { Overall } \\
\text { Results }(\%)\end{array}$ & $\begin{array}{c}1996 \\
\text { Accountancy }\end{array}$ & $\begin{array}{c}1996 \text { Accountancy } \\
(\%)\end{array}$ & $\begin{array}{c}1996 \text { Art and } \\
\text { Design Results }\end{array}$ & $\begin{array}{l}1996 \text { Art and } \\
\text { Design } \\
\text { Results }(\%)\end{array}$ \\
\hline 1 & 236 & 8 & 0 & 0 & 12 & 13.48 \\
\hline 2 & 464 & 16 & 5 & 21.73 & 14 & 15.73 \\
\hline $3 b$ & 422 & 15 & 2 & 8.70 & 20 & 22.47 \\
\hline $3 a$ & 528 & 18 & 5 & 21.73 & 25 & 28.09 \\
\hline 4 & 671 & 23 & 6 & 26.08 & 11 & 12.36 \\
\hline 5 & 403 & 14 & 4 & 17.39 & 4 & 4.49 \\
\hline $5 *$ & 170 & 6 & 1 & 4.34 & 3 & 3.37 \\
\hline Total & 2894 & 100 & 23 & 100 & 89 & 100 \\
\hline
\end{tabular}

Sources: Guardian 2005; University Grants Committee 2005

In stark contrast to the NZ scale, the British RAE had a healthy $39 \%$ of all universities ranked in the highest 5 or $5 *$ categories (Table 3). Yet, the 'Art and Design' discipline faired less well with only $16 \%$ in these elite categories. The 1996 results show a similar trend albeit with lower elite scores in both the overall results and the "Art and Design' discipline. The same cannot be said however for the Accounting and Finance disciplines as the 2001 results demonstrated that $70 \%$ rising to be placed within the 5 or $5^{*}$ categories. This result is seen to be a vast improvement on the results seen in 1996 where only $21.73 \%$ fell into the 5 and $5 *$ categories. However when looking at these results its important to note the fact that there were only 20 overall contributing schools/disciplines in the area of Accounting and Finance and 75 in the Art and Design disciplines, compared with 2598 total number of school/divisions included in the overall examination. The improvement in the accounting ratings could be a result of: 1) improved performance of all British academics as they realise the growing importance of quality research over time, or 2) they better learn how the system works and use gaming strategies (such as level of unit to be assessed at) to maximise their results, or 3) the UK accounting and finance academics may well system grade higher than their Australasian brethren. 
Tables 2 and 3 data results show mixed results for visual arts and accounting academics. Overall, there is improvement shown in the UK experience (especially for accountings) yet the average scores for each discipline have generally been low (especially in New Zealand). There are several reasons for the lower ratings for visual arts and accounting academics in these national research assessment exercises:

- $\quad$ There are lower levels of scholarly research training with art and accounting academics having one of the lowest levels of doctoral training for academics (in Australia it is below $40 \%$ and just over $40 \%$ respectively Desai et al (2005)). Within the visual arts until the mid 1990s the level of educational achievement in countries such as Australia and New Zealand was a BA, then the MA by research and course work were embraced as most other disciplines were moving to gain $\mathrm{PhDs}$, only recently has the $\mathrm{PhD}$ qualification and the respected echelon of research attained at that stage of academia been embraced by the visual arts academia. In accounting the overall percentages whilst low is growing steadily. The number of accounting academics who are currently undertaking doctoral studies is relatively high, and therefore these staff are currently less research active as they will not have enough time to be conducting research which is recognised under current guidelines. Finally, there are lower numbers of visual arts and accounting staff with doctoral qualifications which in turn leads to there being a major drain on the resources available to supervise doctoral students.

- $\quad H i g h e r$ teaching loads: Accounting and Visual Arts staff receive teaching and research appointments. There are no research only staff in most universities. Recognised mentors for theoretical research are very generous in helping new researchers in the field, but the challenge for most practice based researchers is to find the time away from practice to write. The challenge for both disciplines is their very high student/staff ratios they teach with (as compared to science disciplines) and to manage this high teaching load and find time to prioritise research. There are many factors including increasingly large class sizes, frequent international teaching assignments (especially for business disciplines such as accounting) and higher administrative workloads which are seen to be increasingly hindering the research process by such staff.

- $\quad$ Lower availability of grants: There are lower amounts available for social science research and the lower scholarly refereed journal track record output by visual art and accounting academics makes it more difficult to compete against other more established science or social science disciplines. Therefore, there is also very little monies available for research assistance to develop to the level of research produced in other areas of academia. The limited number of competitive grants obtained by accounting and visual arts academics may be explained by the inexpensive nature of research in the field. Accounting academics do not normally require anywhere near the level of funding that science researchers frequently require. Furthermore, areas of research within the accounting/finance and visual arts areas are often seen as less important that those of the medical and legal areas, therefore funding is nowhere near as readily available to this area. Moreover, visual art academics have the additional difficulty of gaining recognition for their non-traditional style of research output.

- $\quad$ More individualistic nature of visual art research outputs: Often university research output is greatly magnified by research groups such as large science-based laboratories. In the visual arts groups of researchers are rarer, the individual time consuming nature of practice based research produces far less output and hence less recognition at assessment exercises. The visual arts practice based research is very ego-centric personal research, based in research methods that often exclude mentoring, or obscurity eludes others input other than aesthetically so the level of mentoring is often not measurable. (Desai et al 2005; Ridgewell and Tower, 2005).

In addition to this above list, Wise and Fisher (2005) note that within low consensus disciplines such as accounting and finance and the visual arts, it is extremely problematic to define prominent publication outlets.

\section{Australia: Present And Proposed Research Assessment Models}

Over three billion dollars are spent on research for Australian universities (Leeder, 2005). Geuna \& Martin (2003) summarise the current Australian model as a combination of an institutional operating grant with a separate, targeted grant scheme. There are three components to the targeted portion. 
- $\quad$ Research Training Scheme (RTS): Funds are allocated based on 40\% research income, 50\% research student completions and $10 \%$ research publications.

- $\quad$ Research Infrastructure Block Grant (RIBG). These is wholly allocated on the relative success of each institution in obtaining research funds based on Australian competitive grants (in other words 100\% inputs focused measured as research income, with no percentage weightings to research student completions or publications outputs).

- $\quad$ Research Quantum. This was originally $100 \%$ based on past grant success record of a university, but due to criticisms was slightly widened (Guena and Martin, 2003). The current weightings are $60 \%$ research income, $30 \%$ research student load and $10 \%$ research publications (RQF, 2005).

Overall, the above criteria have two major flaws: the distorted allocation of input versus output measures and the focus on quantity and not quality. The percentage weightings of the three research schemes clearly disadvantages schools such as visual arts since it is primarily driven on past grant success. Those universities with medical schools and/or large science labs are likely to get the lion share of the funds. Another major criticism of the current Australian system is its rules-based mechanistic nature. Bourke (1997, p.25) argues the inadequate nature of such a system as it "is confined to counting annually the gross number of undifferentiated entrants each institution can place in the classification categories which are weighted for funding purposes." The focus is purely on the quantity of inputs (grants) and outputs (supervision completions and publications/exhibits. There is no focus on the quality of the contribution (outcomes) (Desai et al 2005; Ridgewell and Tower, 2005).

Over the last decade Australian university rankings are made with the announcement of successful Australian Research Council national granting rounds. While these rankings may be useful for marketing purposes, these sorts of measures aren't necessarily transparent in what has been achieved nor do they drive quality improvement related behaviours. Additionally there are major criticisms at comparing different types of institutions, i.e. one with a medical school and one without (RQF, 2005a). An overview of the implications and problems with this shift of emphasis in Australia is presented in Table 4.

Table 4 highlights the rapid changes in the Australian university environment. It documents the rapid progression from being substantially academically driven to being more market driven. Government contributions to the university sector have diminished substantially and therefore have forced universities to look at other ways of raising revenue.

Table 4 also highlights concerns about the inadequacies of past performance indicators in measuring research productivity and allocating research funds. The Australian federal government is thus now in the process of instituting a form of research assessment exercise for universities. The Research Quality Framework: Assessing the quality and impact of research in Australia was released as an Issues paper in 2005. The Federal Minister for Education, Dr Brendan Nelson, states "An RQF will provide a consistent and comprehensive approach to assessing publicly funded research. It will drive positive research behaviours, encouraging researchers and research organisation to focus on the quality and impact of their research. The Australian Government is committed to ensuring that resources provided to carry out research are directed to areas of research excellence and public benefit" (Minister's Foreword, 2005, p.1). An Expert Advisory Group for an RQF was established in 2004. The Chair is Sir Gareth Roberts, the individual that lead the 2003 review of the UK RAE and one of the panel members is Professor Paul Callaghan, Chair of Moderation Panel for the New Zealand Performance Based Research Fund. Therefore, as expected, the Australian RQF theme ${ }^{1}$ is

\footnotetext{
${ }^{1}$ There are several controversial elements. Healy (2005a) argues that splitting universities as research-oriented or non-research oriented is false dichotomy. Yaman (2005, p.37) notes that the result may well be zero research funds for some. Healy, quoting James, argues that "The Federal Government's research agenda encouraged research in 'priority areas' that copied international headline trends, concentrated funding a few hands, emphasised science-oriented research and set up expectations of commerciallyapplicable research and dreams of generating wealth ...All of these ... have almost nothing to do with quality... Intellectual scientists of the last generation ...must be turning in their graves" (2005a, p. 13). Healy (2005b) notes the RQF paper reinforces the potentially widening division of academic labour. In a similar view the National Tertiary Education Union "has criticised the suggestion that the requirement be removed for potential university aspirants to engage in research and offer a broad range of disciplines, stating it would lower standards and reduce quality across the sector... and will merely reduce diversity and encourage
} 
largely consistent with the earlier UK and NZ initiatives (Research Quality Framework, Advanced Approaches Paper, 2005b).

Table 4: Rapid Changes In The Australian University Environment

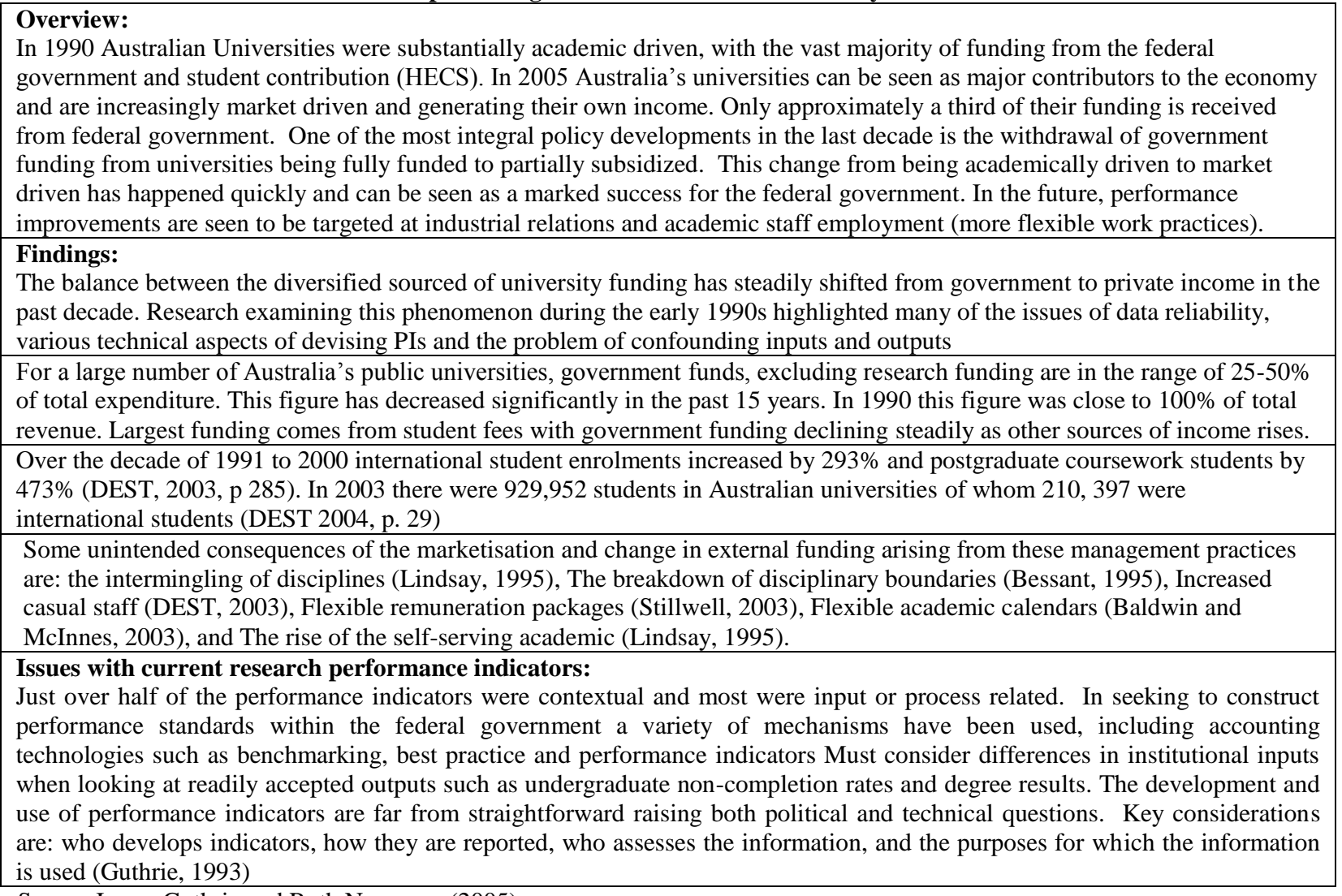

Source James Guthrie and Ruth Neumann (2005)

Another important concern of accounting and visual arts disciplines is the overuse of citation indices to measure an academics research performance. Authors such as Harnad, et al (2003) and others advocate greater use of citation measures by national assessment exercise bodies. They feel that use of more objective and quantifiable indicators such as Journal Impact Factors (JIF) is a better and less subjective way of measuring research performance. Harnad et al (2003), in an in-depth study, found that there is a high correlation (above .80) of the JIF with sciencebased disciplines in the UK RAE assessments. However, there are problems with applying such a performance indicator to business and humanities. One problem is that with the main Social Science Citation Index (SSCI) only six of 1800 journals are accounting-based with little geographic spread (five USA and one UK). Another problem is that it completely ignores practice-based disciplines such as visual arts where no such index is easily calculated based on art works.

\section{FUTURE PORTENTS FOR BUSINESS AND HUMANITIES}

We find incentives and impediments in the structure of national research exercise systems. The current definition of research in Australia (and other countries) is broad enough to include most of the activities of visual arts

institutions into destructive competition against each other on a narrow range of highly profitable disciplines" (The Australian, 2005, p.13). 
and accounting and finance academia. However, the actual way of operationalizing the measurement models excludes many current activities. The need to clearly demonstrate quality peer review is the largest hurdle. This paper provides analyse of the likely introduction of a 'quality assessment exercise' in Australia based on the recent New Zealand and UK experiences (Tertiary Education Commission. 2004; RAE, 2001). Whilst both visual arts and accounting and finance academia research performance activity was generally ranked low in both countries, we find that their move towards quality and peer assessment offers a potentially broader and more accurate depiction of activity. Obtaining a balanced broader assessment of both traditional research performance measures such as research publications along with the more creative elements of visual arts such as exhibitions is paramount.

The federal government is cognizant of these concerns and has explicitly stated the importance of adopting a framework that allows disciplines such as visual arts and accounting and finance a balanced assessment. "The metrics should be able to be adjusted according to the particular shape of disciplines. For example, in the arts and humanities, it may be more relevant to include performances, exhibitions, and other esteem indicators, whereas in the sciences, more focus might be given to citations indices" (RQF, 2005, Section 2.3). Yet, the RQF itself follows the above noteworthy concepts with a key table listing a very narrow set of examples of possible metrics. The aim may well be worthy, but the devil may thus be in the details.

\section{CONCLUSIONS}

For both disciplines reviewed in this study there are many positive aspects that should be highlighted. National research assessment exercises have several important advantages for disciplines in humanities and business not historically well regarded from a research perspective by the higher education sector. We argue that universities are currently undercounting visual art performance because of problems documenting research activity. The implementation of a national research assessment exercise may assist the visual arts discipline by: 1) providing an expert panel of peer reviewers that understand the value of performances and exhibitions 2) provide a funding mechanism system that places far greater focus on research outputs (production) and a concurrent lesser focus on research grants. This is arguably much fairer for a social science discipline. Similarly, a greater focus on research outputs (as evaluated by peers) puts the accounting discipline on fairer assessment criteria than use of an input measure such as research grants.

The overall low research productivity levels in past national RAEs show that visual arts and accounting and finance academics still struggle to compete with other university disciplines. We argue the need for the discipline to evolve an acceptable peer review system to better access their broad research activities is paramount. The implementation of a national research assessment system provides new opportunities to reward a wide range of disciplines. A positive aspect of the RAE debate is greater recognition by visual arts academics of the crucial importance of communicating their research in both practice-based and scholarly-based venues and a higher priority towards research for accounting academics. Globally, art and business are crucially dependent on the creative and scholarly contributions of the accounting and visual art academic community. They highlight the communication and creation of national treasures for the betterment of society. A comprehensive, effective system to assess and reward visual art and accounting research output should greatly assist the ability of these professions to be rewarded for their research contributions.

\section{ACKNOWLEDGMENTS}

The authors would like to thank Alistair Brown, Emily Goforth and the participants of the Accountability Interest Group, Accounting and Finance Association of Australia and New Zealand for their invaluable insights and suggestions on earlier drafts of this paper. Funding from the Curtin Business School Tier 1 grants is gratefully acknowledged. 


\section{REFERENCES}

1. Baldwin, G. and McInnis, C., (2002), The Organisation of the Academic Year: Trends, Implications and Issues, Department of Education, Science and Training, Commonwealth of Australia.

2. Bessant, B. (1995), Corporate management and its penetration of university administration and government, The Australian Universities Review, vol 38, No 1 pp 59-62.

3. Bourke, P. (1997). Evaluating University Research: The British Research Assessment Exercise and Australian Practice, Commissioned Report No. 56, Canberra: national Board of Employment Education and Training.

4. $\quad$ Carnegie Foundation's Special Report entitled Scholarship Reconsidered, 1990.

5. Desai, R., Carson, B., Cheng, S., and Tower, G., (2005) Reflections on Australian Accounting Academics' Research Performance, Accounting and Finance Association of Australia and New Zealand Annual Conference, Melbourne, Australia.

6. Geuna, A. and Martin, B.R., (2003) University Research evaluation and funding: An International Comparison, Minerva (41), 277-304.

7. Guthrie, J. and Neumann, R., (2005), Performance Indicators in Universities: The Case of the Australian University System and Performance Driven System, $28^{\text {th }}$ Annual congress of the European Accounting Association, Goteborg, Sweden.

8. Guthrie, J. (1993) Performance Measurement Indicators in the Australian Public Sector, in Buschor, E., (ed), Perspectives on Performance and Public Sector Accounting, UPT Publishers, Berm , Switzerland, 1993, pp 259-277.

9. Harnad, S., Carr, L., Brody, T., and Oppenheim, C. (2003). Mandated Online RAE CVs Linked to University Eprint Archives: Enhancing UK Research Impact and Assessment, Ariadne, Issue 35, 1-16.

10. Healy, G. (2005a). RQF Offering Crumbs From the Rich Man's Table, Campus Review, 30 March 2005, p.1, 13.

11. Healy, G. (2005b). On a Sliding Scale: RQF Looks at Rankings and Ratings, Campus Review, 6 April, 2005, p.5.

12. Leeder, S. (2005). Research for the Good of Everyone, The Australian, 6 April, 2005, p.32.

13. Lindsay, A., (1995), Collegiality and Managerialism: What is the Place of Leadership in Higher Education?, Professorial Inaugural Lecture, Macquarie University, Sydney, Australia, 6 November.

14. Lucas, L. (2004). Linking Research and Teaching: The significance of research funding and evaluation policies, Research and Teaching: Closing the Divide? An international colloquium, Marwell Conference Centre, Winchester, England, 18-19 March 2004.

15. Minister's Foreword (2005). In RQF [Research Quality Framework], A Research Quality Framework: Issues Paper, Commonwealth of Australia: Canberra.

16. OECD (1987). Universities Under Scrutiny, OECD: Paris.

17. Plummer, K. (2005). University of Auckland academic, Personal correspondence.

18. Ridgewell, B. and Tower, G., (2005), University Performance Evaluation: the Business of Research, Journal of College Teaching \& Learning, in press.

19. RQF [Research Quality Framework], (2005). A Research Quality Framework: Issues Paper, Commonwealth of Australia: Canberra.

20. RQF [Research Quality Framework]. (2005). Research Quality Framework: Assessing the Quality the Impact of Research in Australia: Advanced Approaches Paper, Commonwealth of Australia: Canberra.

21. Stilwell, F., (2003), Markets in Merit... or Merit in Markets?, Australian Universities Review, Vol. 72, No. 6, pp 730-750.

22. The Australian (2005b). Discussion Paper on University Protocols, 3 April, 2005, p.13.

23. University Grants Committee (UK) (2005). RAE Guidance Notes, University Grants Committee: Hong Kong.

24. Wise, V. and Fisher, C., (2005) Refereed Journal Output: A Regional Perspective, Unpublished working paper, Melbourne University.

25. Van Peursem, K. (2004). Waikato University academic, Personal correspondence.

26. Yaman, E. (2005), Zero Research Funds for Some, The Australian, 20 April, 2005, p.37. 


\section{WEB REFERENCES}

1. Department of Education, Science and Training, (2003), The National Report on Higher Education in Australia 2001, Available; www.detya.gov,au/highered/otherpub/ national_report/default.htm.

2. Geuna, A. and Martin, B. R., University Research Evaluation and Funding: An International Comparison . Accessed on March 23, 2005 from http://www.sussex.ac.uk/spru/1-6-1-2-1.html.

3. Guardian About the Tables, Assessed on April 14, 2005 from http://education.guardian.co.uk/secondaryschoolsguide.story/0,11228,602663,00.html.

4. Higher Education and Research Opportunities, Panels' Criteria and Working Methods, Accessed March 23, 2005 from www.hero.ac.uk/rae/criteria/crit64.htm.

5. Higher Education and Research Opportunities, A Guide to the 2001 Research Assessment Exercise, Accessed on April 42005 from http://195.194.167.103/Pubs/other/raeguide.pdf.

6. Tertiary Education Commission, PBRF Definition of Research Accessed on April 42005 from http://www.otago.ac.nz/research/pbrf/\#definition.

7. University Grants Committee, Appendix 1., Accessed on April 192005 from http://www.ugc.edu.hk/eng/ugc/publication/prog/rae/appenda.htm.

8. University Grants Committee, Research Assessment Exercise 2006: Information Note, Accessed on April 13 2005 from http://www.ugc.edu.hk/eng/doc/ugc/publication/prog/rae/rae2006.pdf. 


\section{NOTES}

